\title{
Qiong Zhang
}

Making the New World Their Own: Chinese Encounters with Jesuit Science in the Age of Discovery. Leiden: Boston: Brill, 2015. Pp. xx + 435. Hb, \$218.

The title of this fine study of the relationship between Jesuit missionaries and Chinese scholars shows that the author is determined to explore the Chinese side of that relationship far more than other recent studies of the Jesuits in China. Rather than a Eurocentric view of a "New World," which focusses on the Americas, Zhang relates how encounters with Europeans and, more important, encounters with Jesuits enabled late Ming- and early Qing-dynasty China to adopt a new picture of the world.

Like other studies of the relationship between Jesuits and science in China, Zhang begins with Matteo Ricci, who arrived in China in 1582. But Zhang does not focus on the mathematics and astronomy that gave Ricci entrée into Mandarin society. Rather she focuses on cartography, an area that has received inadequate attention. In 1602, Ricci drew a map of the world for his Chinese hosts, and that map ultimately led Chinese scholars to redraw their map. Chinese scholars in the late sixteenth century depicted China as the center of a square earth surrounded by four seas. This picture was based on Confucian classics. Ricci introduced the Western concept of the terraqueous globe, a sphere that had no center on the surface. The Chinese scholars were loath to adopt this view, and at first it seemed that Ricci's map would go nowhere. Ricci did, on the other hand, invent Chinese names for Western geographical concepts, words that are still used today. As an example, Zhang mentions the Chinese name for planet Earth, "Diqiu," which means terrestrial sphere. Perhaps more important for the acceptance of his map, Ricci, in good Jesuit fashion, suggested that the ancients texts that described a square earth and the four seas need not be read literally. This proved very fruitful, for it encouraged later generations of Chinese scholars to promote the Western concept of the terraqueous globe. Indeed, there was also a Chinese tradition going back to the twelfth century claiming that the concept of the four seas was not meant to be taken literally, but by the time Ricci arrived in China, this tradition had long been ignored. Zhang shows that despite that older tradition there was definite Jesuit influence on the acceptance of the Western map, especially on the scholars that she identifies as "Yugong," the Tribute of Yu; nevertheless, Chinese scholars began to see the origin of the terraqueous globe in their classical texts and to attribute Western learning to Chinese sources. By 1712, the new official imperial map, the Kangxi Atlas, just over one hundred years after Ricci presented his map, demonstrated an acceptance of Western cartography. "This map, couched in a simple mathematical language, was itself the statement" (265). As Zhang points out, it was 
the culmination of nearly two centuries of Chinese engagement with Western Europe and represented the Kangxi emperor's cultural and territorial ambitions in two ways. On the one hand, there were the social and geopolitical aspects of that engagement that included commerce and empire. On the other hand, there were the cultural and intellectual aspects and in particular studies of the natural world that were "filtered into China through the Jesuits" (267).

The Jesuit mission in Chinese could have been derailed by the old Chinese myth of a monstrous, cannibalistic people called the Folangji. The often aggressive nature of the European explorers and colonizers in the East led to their identification with the Folangji by many Chinese scholars, and that forced the Jesuits to strive not to be identified in the Chinese imaginations with other Europeans they had encountered. Zhang relates how the convert Xu Guangqi, a member of Ricci's inner circle, spread the idea within Beijing that the Spanish and the Jesuits were not of the same religion as those other Europeans, as evidenced by the fact that they worshipped different deities: the former worshipped "Dios" while the latter worshipped "Deus." Zhang traces the origin of the myth of the Folangji to medieval Muslim travelers who used the word for the Franks, and it was then applied to all Western Europeans. Zhang also informs us that this myth of the Folangji was the source of the Ferengi in the Deep Space Nine spin-off of Star Trek.

As ships were encircling the globe in the sixteenth and seventeenth centuries, cartography became an important science. Zhang shows us how the adoption of Western cartography in China allowed the Chinese to become part of this global enterprise, and how the Jesuits played a crucial role in facilitating that adoption.

\author{
Sheila J. Rabin \\ Saint Peter's University \\ srabin@stpeters.edu \\ DOI $10.1163 / 22141332-00303008-10$
}

